\title{
FORMULASI MASKER PEEL-OFF EKSTRAK DAUN KEMANGI (Ocimum sanctum) SEBAGAI SEDIAAN ANTI JERAWAT
}

\section{FORMULATION OF PEEL-OFF MASK BASIL (Ocimum sanctum) LEAVES EXTRACT AS AN ANTI-ACNE PREPARATION}

\author{
Alifia Ramadanti ${ }^{1}$, Dyah Rahmasari ${ }^{1 *}$, Winda Maulana ${ }^{1}$, Desy Erika Rahayu ${ }^{1}$, \\ M. Imam Asshidiq ${ }^{1}$, Raditya Weka Nugraheni ${ }^{1}$ \\ ${ }^{1}$ Program Studi Farmasi, Fakultas Ilmu Kesehatan, Universitas Muhammadiyah Malang \\ Email :dyahrahmasari@umm.ac.id
}

Submitted : 11 Juli 2021 Reviewed : 2 September 2021 Accepted : 22 September 2021

\begin{abstract}
ABSTRAK
Jerawat merupakan gangguan pada folikel pilosebasea yang banyak ditemukan pada remaja. Spesies mikroba yang terlibat dalam patogenesis jerawat adalah Propionibacterium acnes, Staphylococcus aureus, dan Staphylococcus epidermidis. Daun kemangi (Ocimum sanctum) merupakan salah satu tanaman yang memiliki aktivitas antibakteri dan dapat diformulasikan dalam sediaan masker peel-off. Penelitian ini bertujuan untuk mengembangkan dan mengevaluasi masker peel-off yang dibuat dari ekstrak daun kemangi (Ocimum sanctum) yang memiliki aktivitas antibakteri. Ekstrak daun kemangi diperoleh dengan cara maserasi menggunakan pelarut etanol 96\%. Ekstrak kemudian diformulasikan menjadi masker peel-off dengan variasi konsentrasi 6\%, 8\%, 10\%. Dilakukan pengujian terhadap sifat fisikokimia seperti organoleptis, homogenitas, nilai $\mathrm{pH}$, viskositas, daya sebar, dan waktu pengeringan, sedangkan uji aktivitas antibakteri dilakukan dengan metode difusi sumuran. Diameter zona hambat pada uji antibakteri terbesar adalah pada konsentrasi ekstrak $10 \%$ dengan diameter zona hambat $23,13 \mathrm{~mm} \pm 1,82$ terhadap Propionibacterium acne, $11,62 \mathrm{~mm} \pm 0,27$ terhadap Staphylococcus aureus, dan $21,21 \mathrm{~mm} \pm 1,72$ terhadap Staphylococcus epidermidis. Dapat disimpulkan bahwa masker peel off ekstrak daun kemangi paling efektif terhadap Propionibacterium acne yang termasuk dalam kategori efek antibakteri kuat.
\end{abstract}

Kata kunci : Ekstrak daun kemangi (Ocimum sanctum), Masker Peel-off, Anti-jerawat, Propionibacterium acnes, Staphylococcus aureus, Staphylococcus epidermidis

\begin{abstract}
Acne is a pilosebaceous disorder which commonly found in teenagers. The species of microbes that are involved in acne pathogenesis are Propionibacterium acnes, Staphylococcus aureus, and Staphylococcus epidermidis. Basil (Ocimum sanctum) leaves is one of the plants which has antibacterial activity and could be formulated in a peel-off mask preparation. The aims of this research are to develop and evaluate a peel-off mask prepared from basil (Ocimum sanctum) leaves extract, which has antibacterial activity. Basil leaves extract was obtained by maceration using $96 \%$ of ethanol solvent. Then, the extract was formulated into peel-off mask with varying concentration of 6\%, 8\%, 10\%. Physicochemical properties such as organoleptic, homogeneity, $\mathrm{pH}$ value, viscosity, spreadability, and drying time were tested, while antibacterial activity test was conducted by the well-diffusion method. The largest diameter of inhibition zone of antibacterial evaluation is at an extract concentration of $10 \%$ with a diameter of the inhibition zone are $23,13 \mathrm{~mm} \pm 1,82$ against Propionibacterium acne, $11,62 \mathrm{~mm} \pm 0,27$ against Staphylococcus aureus, and 21,21 mm \pm
\end{abstract}


1,72 against Staphylococcus epidermidis. It can be concluded that the peel-off mask of basil leaves extract is the most effective in Propionibacterium acne which categorized as powerful antibacterial effect.

Keywords: Basil (Ocimum sanctum) leaves extract, Peel-off mask, Anti-acne, Propionibacterium acnes, Staphylococcus aureus, Staphylococcus epidermidis.

\author{
Penulis Korespondensi : \\ Alifia Ramadanti \\ Universitas Muhammadiyah Malang \\ Email : dyahrahmasari@umm.ac.id
}

\title{
PENDAHULUAN
}

Jerawat merupakan salah satu masalah infeksi kulit yang banyak terjadi pada remaja. Jerawat salah satu infeksi kulit berulang yang dapat menurunkan kepercayaan diri hingga menyebabkan stress. Seringkali jerawat dapat meninggalkan bekas luka permanen pada wajah (Sutanto, 2013). Ada empat proses yang berhubungan dengan timbulnya jerawat yaitu produksi sebum yang meningkat, peluruhan dari keratinosit, pertumbuhan bakteri dan peradangan. Organisme yang berperan dalam patogenesis jerawat adalah Propionibacterium acnes, Staphylococcus aureus, dan Staphylococcus epidermidis. Pengobatan jerawat biasanya menggunakan antibiotik untuk mengurangi jumlah bakteri seperti eritromisin dan klindamisin. Namun, penggunaan antibiotik dalam jangka panjang dapat menimbulkan resistensi serta dapat merusak organ (Walsh et al, 2016).

Daun kemangi (Ocimum sanctum) merupakan salah satu tanaman yang memiliki aktivitas antibakteri dan dapat diformulasikan dalam sediaan masker peel-off. Beberapa golongan kandungan bahan aktif yang ada pada daun kemangi juga berpotensi sebagai bakteriostatik dan bakteriosida seperti senyawa minyak atsiri, fenol dan alkaloid. Ekstrak etanol daun kemangi (Ocimum sanctum) dapat digunakan sebagai penghambat pertumbuhan bakteri penyebab jerawat yang hidup dan berkembang biak dengan mudah pada daerah kulit (Ali and Dixit, 2012). Umumnya untuk menjaga keseimbangan dan elastisitas kulit digunakan berbagai macam variasi kosmetik, salah satunya adalah masker peel-off. PVA dipilih sebagai basis pada sediaan masker peel-off yang berfungsi sebagai pembentuk lapisan film yang bersifat biodegradable dan biocompatible dimana dapat menghasilkan peel-off gel yang cepat kering dengan lapisan film yang transparan, kuat, plastis dan melekat baik pada kulit (Andini et al, 2017). PVA merupakan polimer biodegradable ramah lingkungan, yang mampu menghasilkan lapisan tipis yang baik pada kulit (Asthana et al., 2021). Pada penelitian sebelumnya yang dilakukan oleh Arinjani dkk (2020), menunjukkan bahwa konsentrasi PVA sebagai plasticizer pada masker peel-off menunjukkan hasil karakteristik fisik yang baik meliputi $\mathrm{pH}$, viskositas, daya lekat, daya sebar dan waktu mengering pada konsentrasi $10 \%$.

Pada penelitian sebelumnya yang dilakukan Tambajong (2017), ekstrak daun kemangi (Ocimum sanctum L.) memberikan pengaruh terhadap pertumbuhan bakteri Staphylococcus epidermidis dalam konsentrasi $10 \%$ dengan rata - rata zona hambat adalah $9,2 \mathrm{~mm}$. Menurut Septianindri (2015) esktrak etanol daun kemangi (Ocimum sanctum) dalam kadar $15 \%$ memiliki zona hambat $3,5 \mathrm{~mm}$ terhadap bakteri Propionibacterium acnes. Sedangkan menurut Angelina ( 2015) zona hambat esktrak etanol daun kemangi (Ocimum sanctum) terhadap bakteri Staphylococcus aureus dengan kadar 20\% adalah seluas 12,10 $\mathrm{mm}$. Berdasarkan temuan tersebut ingin dikembangkan ekstrak daun kemangi dalam bentuk sediaan peel-off anti-acne yang mudah digunakan masyarakat. Penelitian ini bertujuan untuk mengetahui karakteristik fisikokimia dan aktivitas antibakteri dari sediaan masker peel-off yang dikembangkan menggunakan ekstrak daun kemangi (Ocimum sanctum). 


\title{
METODE PENELITIAN
}

\begin{abstract}
Alat dan Bahan
Alat yang digunakan untuk penelitian ini adalah analitical balance (Metler Toledo), pH meter (Schott), viskometer (Brookfield), autoklaf, bunsen, jarum ose, cawan petri (Pyrex), inkubator (Memmert), jangka sorong, mikropipet, stopwatch dan seperangkat alat gelas.

Bahan-bahan yang digunakan dalam penelitian ini adalah ekstrak daun kemangi (Ocimum sanctum $\mathrm{L}$ ) yang diperoleh dari Materia Medica Batu, Indonesia, polivinil alcohol (PVA), propilenglikol, propil paraben, metil paraben, etanol 96\%, kristal violet, lugol, safranin, nutrient agar, Clindamycin gel dan aquadest, serta bakteri Staphylococcus aureus, Staphylococcus epidermidis, dan Propionibacterium acne.
\end{abstract}

\section{Pembuatan Masker Peel-Off Ekstrak Daun Kemangi}

Masker peel-off ekstrak daun kemangi dibuat sesuai dengan formula pada Tabel I. Pembuatan masker diawali dengan menimbang semua bahan lalu dilanjutkan dengan mengembangkan PVA menggunakan aquadest sebanyak 3 kali bobot PVA dan dipanaskan hingga mengembang sempurna membentuk basis peel-off. Metil paraben dan propil paraben dilarutkan dalam propilenglikol. Setelah campuran PVA dingin, semua bahan dan sisa aquadest dicampur dan ditambahkan ekstrak daun kemangi yang telah dilarutkan dengan etanol 96\% sedikit demi sedikit sambil diaduk hingga homogen.

Tabel I. Formulasi Masker Peel-off Ekstrak Daun Kemangi

\begin{tabular}{lccc}
\hline \multirow{2}{*}{ Bahan } & \multicolumn{3}{c}{ Formula (\%) } \\
\cline { 2 - 4 } & $\mathbf{1}$ & $\mathbf{2}$ & $\mathbf{3}$ \\
\hline Ekstrak daun kemangi & 6 & 8 & 10 \\
\hline PVA & 10 & 10 & 10 \\
\hline Propilenglikol & 15 & 15 & 15 \\
\hline Metil Paraben & 0,2 & 0,2 & 0,2 \\
\hline Propil Paraben & 0,1 & 0,1 & 0,1 \\
\hline Etanol 96\% & 15 & 15 & 15 \\
\hline Parfum & $\mathrm{qs}$ & $\mathrm{qs}$ & $\mathrm{qs}$ \\
\hline Aquadest & ad 100 & $\mathrm{ad} 100$ & $\mathrm{ad} 100$ \\
\hline
\end{tabular}

\section{Evaluasi Karakteristik Fisikokimia Masker Peel-Off Ekstrak Daun Kemangi}

Evaluasi yang dilakukan meliputi pengamatan organoleptis dan homogenitas, penentuan nilai $\mathrm{pH}$, viskositas, daya sebar dan waktu mengering sediaan. Pemeriksaan organoleptis dilakukan dengan mengobservasi warna, bau dan tekstur dari sediaan secara visual (Al Muazham and Husnani, 2017). Homogenitas diamati secara visual terhadap adanya butiran kasar pada sediaan. Penentuan nilai $\mathrm{pH}$ dilakukan menggunakan $\mathrm{pH}$ meter digital dan nilai viskositas menggunakan viskometer. Daya sebar ditentukan dengan meletakkan sejumlah sediaan diantara dua preparat kaca yang diberikan sejumlah beban (Saptarini and Hadisoebroto, 2020). Sedangkan waktu mengering dilakukan secara in-vitro menggunakan stopwatch dengan mengoleskan sediaan pada kaca objek dan dimasukkan ke dalam incubator pada suhu $37^{\circ} \mathrm{C}$ (Rompis et al, 2019).

\section{Pengujian Aktivitas Antibakteri \\ Sterilisasi Alat}

Media dan alat-alat yang dibutuhkan untuk pengujian, disterilkan menggunakan autoklaf pada suhu $121^{\circ} \mathrm{C}$ selama 15 menit. Selanjutnya untuk jarum ose dan pinset dibakar diatas api bunsen langsung (Afni et al, 2015).

\section{Preparasi Media}

Dalam penelitian ini digunakan media yaitu Nutrient Agar (NA). Pembuatan media ini dilakukan dengan melarutkan bahan sebanyak 28gram kedalam $1 \mathrm{~L}$ aquadest pada 
erlenmeyer dengan kapasitas $1 \mathrm{~L}$. Erlenmeyer tersebut diletakkan diatas hot plate dan diaduk menggunakan magnetic stirrer untuk mempercepat pelarutan sampai didapatkan larutan media menjadi berwarna kuning jernih. Setelah itu erlenmeyer ditutup dengan aluminium foil kemudian disterilisasi dengan autoklaf selama 15 menit pada suhu $121^{\circ} \mathrm{C}$. Dituang media steril ke cawan petri steril secara aseptis (Afni et al, 2015).

\section{Pembuatan Standar Mc Farland}

Standar Mc Farland dibuat dengan cara menambahkan aquadest ke dalam tabung reaksi. Kemudian tambahkan $\mathrm{H}_{2} \mathrm{SO}_{4} 1 \%$ sebanyak $9950 \mu \mathrm{L}$ dan $\mathrm{BaCl}_{2} 1 \%$ sebanyak $50 \mu$ l. dan kocok hingga homogen dan terbentuk larutan keruh (Standar McFarland 0,5). Kekeruhan ini dipakai sebagai acuan suspensi bakteri dengan tingkat kekeruhan $10^{8} \mathrm{CFU} / \mathrm{ml}$ (Kindangen et al, 2018).

\section{Pembuatan Suspensi Bakteri Uji}

Bakteri uji dari hasil peremajaan agar miring diambil dengan kawat ose steril lalu diinokulasikan ke dalam tabung yang berisi $10 \mathrm{ml}$ larutan $\mathrm{NaCl}$ 0,9\% hingga diperoleh kekeruhan yang sama dengan standar kekeruhan larutan Mc. Farland. Perlakuan yang sama dilakukan pada setiap jenis bakteri uji.

\section{Uji aktivitas antibakteri secara In-vitro}

Uji aktivitas antibakteri secara in-vitro dilakukan dengan metode difusi sumuran. Sediaan masker peel-off ekstrak daun kemangi dengan variasi kadar yang berbeda $(6 \%, 8 \%$ dan 10\%) diletakkan pada lubang sumur yang berbeda sebanyak $100 \mu$ l. Selanjutnya, basis sediaan tanpa bahan aktif yang digunakan sebagai kontrol negatif, diteteskan pada lubang sumur sebanyak $100 \mu \mathrm{l}$. Clindamycin gel yang digunakan sebagai kontrol positif, diteteskan pada lubang sumur dan diteteskan sebanyak $100 \mu \mathrm{l}$. Kemudian cawan petri diinkubasi dalam inkubator pada suhu $37^{\circ} \mathrm{C}$ selama 24 jam (Afni et al, 2015).

\section{Pengamatan dan Pengukuran}

Pengamatan dilakukan setelah 1x24 jam masa inkubasi. Daerah bening merupakan petunjuk kepekaan bakteri terhadap sampel yang diujikan. Aktivitas antibakteri dinyatakan dengan mengukur lebar diameter zona hambat menggunakan jangka sorong (Afni et al, 2015).

\section{Analisis Data}

Data hasil evaluasi organoleptis dan homogenitas dianalisis menggunakan metode analisis deskripstif. Sedangkan data yang bersifat kuantitatif dianalisis secara statistik dan disajikan dalam bentuk tabel.

\section{HASIL DAN PEMBAHASAN}

\section{Evaluasi Fisikokimia Masker peel-off Ekstrak Daun Kemangi (Ocimum sanctum)}

Hasil pemeriksaan organoleptis masker peel-off ekstrak daun kemangi (Ocimum sanctum) berwarna hijau kecoklatan, berbau khas daun kemangi, dan memiliki tekstur yang kental. Warna sediaan dipengaruhi oleh warna ekstrak daun kemangi, sesuai yang terlihat pada Gambar 1. Secara visual, ketiga formula dapat dikatakan homogen karena tidak adanya butiran kasar pada uji homogenitas. Hasil pengukuran $\mathrm{pH}$, viskositas, daya sebar dan waktu mengering, ditunjukkan pada Tabel II.
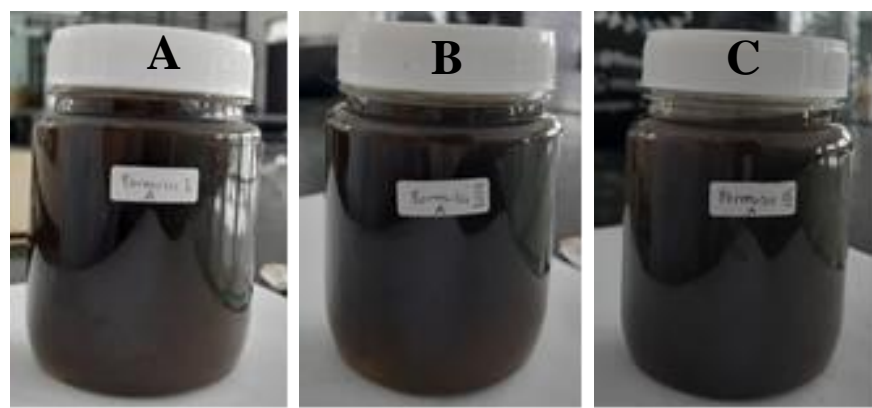

\section{Gambar 1. Sediaan Masker Peel-off Ekstrak Daun Kemangi (a) Formula 1; (b) Formula 2; dan (c) Formula 3}


Tabel II. Hasil Karakteristik Fisikokimia Sediaan Masker Peel-off Ekstrak Daun Kemangi

\begin{tabular}{ccccc}
\hline Formula & pH & Viskositas (cps) & $\begin{array}{c}\text { Daya Sebar } \\
(\mathbf{c m})\end{array}$ & $\begin{array}{c}\text { Waktu Mengering } \\
(\text { menit) }\end{array}$ \\
\hline 1 & $5,84 \pm 0,01$ & $3150 \pm 304,14$ & $3,95 \pm 0,48$ & $33,97 \pm 1,54$ \\
2 & $5,93 \pm 0,04$ & $3816,67 \pm 175,59$ & $3,72 \pm 0,14$ & $36,63 \pm 3,48$ \\
3 & $5,88 \pm 0,01$ & $3400 \pm 360,55$ & $3,49 \pm 0,34$ & $43,67 \pm 2,97$ \\
\hline
\end{tabular}

Penggunaan konsentrasi ekstrak yang berbeda pada sediaan $(6 \%, 8 \%$, dan $10 \%)$ menghasilkan karakteristik yang berbeda pula. Seperti yang terlihat pada Tabel II, nilai $\mathrm{pH}$ sediaan cenderung asam. Hal ini disebabkan karena ekstrak daun kemangi memiliki sifat asam. Namun, nilai $\mathrm{pH}$ tersebut, masih dalam rentang normal $\mathrm{pH}$ kulit yaitu antara 4,5-6,5 (Al Muazham and Husnani, 2017). Hasil viskositas cenderung meningkat dengan adanya penambahan ekstrak. Hal ini kemungkinan dapat disebabkan oleh penambahan ekstrak kental sehingga meningkatkan nilai viskositas sediaan. Hasil uji daya sebar sejalan dengan teori bahwa nilai viskositas berbanding terbalik dengan daya sebar sediaan. Semakin besar nilai viskositas maka semakin kecil kemampuan suatu sediaan untuk menyebar (Deuschle et al., 2015). Penurunan daya sebar ini dapat disebabkan oleh meningkatnya unit partikel dari bahan aktif karena telah mengabsorbsi pelarut sehingga cairan tertahan dan meningkatkan tekanan(Sulastri and Chaerunisaa, 2018). Selanjutnya, pengujian waktu mengering dilakukan untuk melihat waktu yang dibutuhkan sediaan untuk membentuk lapisan pada kulit dan mengering. Berdasarkan Tabel II terlihat bahwa semakin banyak penambahan ekstrak, maka semakin lama waktu yang dibutuhkan sediaan untuk mengering. Hal ini dapat terjadi karena mekanisme kerja PVA yang mengembang dengan cara mengikat air yang ada dalam sediaan, kemudian menyebabkan terjadinya proses tarik-menarik antar molekul air, yang menyebabkan peningkatan kohesivitas. Sehingga semakin banyak ekstrak yang ditambahkan, semakin lama proses pengikatan air yang dilakukan oleh PVA (Warnida et al, 2016). Hasil tersebut belum memenuhi persyaratan untuk waktu mengering masker peel-off yang baik, yaitu 15-30 menit (Ariani and Wigati, 2016). Hal ini dapat dipengaruhi oleh konsentrasi PVA yang digunakan, dimana semakin besar konsentrasi PVA maka semakin cepat waktu mengering sediaan (Warnida et al, 2016).

\section{Aktivitas Antibakteri Masker Peel-off Ekstrak Daun Kemangi}

Aktivitas antibakteri sediaan masker peel-off ekstrak daun kemangi (Ocimum sanctum L.) ditentukan melalui pengamatan diameter zona hambat. Pengamatan dilakukan setelah masa inkubasi 24 jam, dengan 3 kali replikasi untuk masing-masing sediaan masker peel-off. Hasil pengukuran zona hambat ditunjukkan pada Tabel III.

Tabel III. Diameter Zona Hambat Sediaan Masker Peel-off Ekstrak Daun Kemangi (Ocimum sanctum L)

\begin{tabular}{ccc}
\hline Bakteri Uji & Formula & Diameter Zona Hambat (mm) \\
\hline Staphylococcus aureus & 1 & $9,97 \pm 0,41$ \\
& 2 & $11,02 \pm 0,16$ \\
& 3 & $11,62 \pm 0,27$ \\
Staphylococcus epidermidis & $\mathrm{K}+$ & $37,29 \pm 6,55$ \\
& 1 & 0 \\
\hline Propionibacterium acnes & 2 & $16,04 \pm 2,65$ \\
& 3 & $18,69 \pm 1,31$ \\
& $\mathrm{~K}+$ & $21,21 \pm 1,72$ \\
& $\mathrm{~K}-$ & $32,61 \pm 1,23$ \\
& 1 & 0 \\
\hline & 3 & $16,97 \pm 2,07$ \\
& $\mathrm{~K}+$ & $20,63 \pm 2,28$ \\
& $\mathrm{~K}-$ & $23,13 \pm 1,82$ \\
& & $28,89 \pm 0,70$ \\
\hline
\end{tabular}


Berdasarkan Tabel III dapat dilihat bahwa sediaan masker peel-off ekstrak daun kemangi menunjukkan adanya diameter zona hambat terhadap bakteri Staphylococcus aureus, Staphylococcus epidermidis, dan Propionibacterium acne. Diameter zona hambat meningkat secara signifikan seiring dengan adanya penambahan bahan aktif. Hal tersebut diakibatkan adanya aktivitas antibakteri yang dihasilkan oleh kandungan senyawa senyawa metabolit sekunder dalam ekstrak daun kemangi yaitu tanin, flavonoid, dan minyak atsiri. Kandungan tanin mampu membentuk kompleks protein melalui ikatan hidrogen sehingga protein akan terdenaturasi dan mengganggu metabolisme bakteri. Selain tanin, kandungan senyawa flavonoid yang bersifat lipofilik akan merusak membran fosfolipid bakteri sehingga mampu mengurangi permeabilitas dan merusak membran sel bakteri serta keluarnya senyawa intraseluler. Kandungan minyak atsiri dalam ekstrak kemangi juga memiliki daya antibakteri yang kuat sehingga dapat menghambat pertumbuhan bakteri dengan baik (Angelina et al, 2015). Berdasarkan kategori kelompok antibakteri berdasarkan diameter zona hambatnya, sediaan tersebut termasuk kategori kuat untuk bakteri Propionibacterium acne dan Staphylococcus epidermidis serta kategori sedang untuk bakteri Staphylococcus aureus (Lingga et al, 2015). Hal tersebut mengindikasikan adanya potensi dari sediaan masker peel-off ekstrak daun kemangi ini untuk digunakan sebagai terapi pengobatan jerawat.

\section{KESIMPULAN}

Sediaan masker peel-off ekstrak daun kemangi (Ocimum sanctum) dengan variasi kadar 6\%, 8\%, dan 10\% memiliki aktivitas antibakteri terhadap Propionibacterium acne, Staphylococcus aureus, dan Staphylococcus epidermidis. Sehingga sediaan ini berpotensi sebagai alternatif pada terapi pengobatan jerawat.

\section{DAFTAR PUSTAKA}

Afni, N., Said, N., Yuliet, 2015. Uji Aktivitas Antibakteri Pasta Gigi Ekstrak Biji Pinang ( Areca catechu L.) TERHADAP Streptococcus mutans DAN Staphylococcus aureus. $J$. Pharm. 1, 48-58.

Ali, H., Dixit, S., 2012. In vitro antimicrobial activity of flavanoids of Ocimum sanctum with synergistic effect of their combined form. Asian Pacific J. Trop. Dis. 2. https://doi.org/10.1016/S2222-1808(12)60189-3

Andini, T., Yusriadi, Y., Yuliet, Y., 2017. Optimasi Pembentuk Film Polivinil Alkohol dan Humektan Propilen Glikol pada Formula Masker Gel Peel off Sari Buah Labu Kuning (Cucurbita moschata Duchesne) sebagai Antioksidan. J. Farm. Galen. (Galenika J. Pharmacy) 3, 165-173. https://doi.org/10.22487/j24428744.0.v0.i0.8773

Angelina, M., Turnip, M., Khotimah, S., 2015. Uji Aktivitas Antibakteri Ekstrak Etanol Daun Kemangi (Ocimum sanctum L.) terhadap Pertumbuhan Bakteri Escherichia coli dan Staphylococcus aureus. J. Protobiont 4, 184-189.

Ariani, Li.W., Wigati, D., 2016. Formulasi Masker Gel Peel-Off Ekstrak Etanol Kulit Buah Jeruk MAnis (Citrus sinensis (L.) Osbeck) sebagai Obat Jerawat. Media Farm. Indones. 11, 1084-1092.

Arinjani, S., Ariani, L.W., 2020. Pengaruh Variasi Konsentrasi PVA pada Karakteristik Fisik Sediaan Masker Gel Peel-off Ekstrak Daun Ungu (Graptophyllum pictum L. Griff). Media Farm. Indones. 14, 1525-1530.

Asthana, N., Pal, K., Aljabali, A.A.A., Tambuwala, M.M., de Souza, F.G., Pandey, K., 2021. Polyvinyl alcohol (PVA) mixed green-clay and aloe vera based polymeric membrane optimization: Peel-off mask formulation for skin care cosmeceuticals in green $\begin{array}{llllll}\text { nanotechnology. } & J & \text { Mol. } & \text { Struct. } & 1229, & 129592 .\end{array}$ https://doi.org/10.1016/j.molstruc.2020.129592

Deuschle, V.C.K.N., Deuschle, R.A.N., Bortoluzzi, M.R., Athayde, M.L., 2015. Physical chemistry evaluation of stability, spreadability, in vitro antioxidant, and photoprotective capacities of topical formulations containing calendula officinalis L. Leaf extract. Brazilian J. Pharm. Sci. 51, 63-75. https://doi.org/10.1590/S1984- 
82502015000100007

Firdaus Al Muazham, M., Husnani, 2017. Optimasi Parameter Fisik Viskositas, Daya Sebar Dan Daya Lekat Pada Basis Natrium Cmc Dan Carbopol 940 Pada Gel Madu Dengan Metode Simplex Lattice Design. J. Ilmu Farm. dan Farm. Klin. 14, 11-18.

Kindangen, O.C., Yamlean, P.V.Y., Wewengkang, D.S., 2018. Formulasi Gel Antijerawat Ekstrak Etanol Daun Kemangi (Ocimum basilicum L.) Dan Uji Aktivitasnya Terhadap Bakteri Staphylococcus aureus Secara in vitro. Pharmacon 7, 283-293. https://doi.org/10.35799/pha.7.2018.20505

Lingga, A.R., Pato, U., Rossi, E., 2015. Antibacterial Test Of Kecombrang (Nicolaia Speciosa Horan) Stem Extract Againts Staphylococcus aureus and Escherichia coli. JOM Faperta 2.

Rompis, F., Yamlean, P.V.Y., Lolo, W.A., 2019. Formulasi Dan Uji Efektivitas Antioksidan Sediaan Masker Peel-Off Ekstrak Etanol Daun Sesewanua (Cleodendron squamatum Vahl.). Pharmacon 8, 388. https://doi.org/10.35799/pha.8.2019.29305

Saptarini, N.M., Hadisoebroto, G., 2020. Formulation and evaluation of lotion and cream of nanosized chitosan-mangosteen (Garcinia mangostana L.) pericarp extract. Rasayan J. Chem. 13, 789-795. https://doi.org/10.31788/RJC.2020.1325533

Septianindri kurnia, V., 2015. Pengaruh Ekstrak Daun Kemangi (Ocimum americanum L.) Terhadap Pertumbuhan Bakteri Propionibacterium acne Dan Pemanfaatannya Sebagai Buku Non-Teks 27.

Sulastri, A., Chaerunisaa, A.Y., 2018. Formulasi Masker Gel Peel Off untuk Perawatan Kulit Wajah. Farmaka 14, 17-26.

Sutanto, R.S., 2013. Derajat Penyakit Acne Vulgaris Berhubungan Positif Dengan Kadar MDA. Tesis.

Tambajong, J., Naharia, O., Rompas, H.D., 2017. Pengaruh Ekstrak Daun Kemangi ( Ocimum sanctum L.) Terhadap Pertumbuhan Bakteri Staphylococcus epidermidis. $J$. Sains, Mat. dan Edukasi Jur. Biol. FMIPA UNIMA 5, 105-110.

Walsh, T.R., Efthimiou, J., Dréno, B., 2016. Systematic review of antibiotic resistance in acne: An increasing topical and oral threat. Lancet Infect. Dis. 16, e23-e33. https://doi.org/10.1016/S1473-3099(15)00527-7

Warnida, H., Oktaviani, R., Sukawaty, Y., 2016. Formulasi Masker Gel Peel-Off Ekstrak Etanol Umbi Bawang Dayak ( Eleutherine bulbosa (Mill.) Urb.) Husnul. Media Sains 9, 167-173. 
